\title{
MODEL KEPEMIMPINAN KEPALA MADRASAH
}

\section{Hary Priatna Sanusi, M.Ag}

Universitas Islam Negeri Sunan Gunung Djati Bandung JI. A.H. Nasution No. 105, Cibiru Bandung, Jawa Barat, 40614

Email: harypriatna@uinsgd.ac.id

\section{Astuti}

Universitas Islam Negeri Sunan Gunung Djati Bandung

JI. A.H. Nasution No. 105, Cibiru Bandung, Jawa Barat, 40614

Email: Astutisudarta@gmail.com

\begin{abstract}
ABSTRAK
Model Kepemimpin Visioner merupakan kemampuan pemimpin untuk mencetuskan ide atau gagasan suatu visi selanjutnya melalui dialog yang kritis dengan unsur pimpinan lainnya merumuskan masa depan organisasi yang dicita-citakan yang harus dicapai melalui komitmen semua anggota organisasi melalui proses sosialisasi transformasi, implementasi gagasan-gagasan ideal oleh pemimpin organisasi. Dalam mengimplementasikan model tersebut kepala MAS Mu'allimin Manba'ul Huda Kota Bandung memiliki cara tersendiri, diantaranya menciptakan pola komunikasi yang baik dengan semua pihak, menjalin kerjasama dengan stakeholder, terjun langsung kelapangan untuk memotivasi bawahan dan peserta didik serta mencari tahu dan mengasah kemampuan yang dimiliki peserta didik. Metode yang digunakan dalam penelitian ini adalah metode deskriptif-kualitatif-analitik. Teknik pengumpulan data dilakukan berdasarkan teknik pengumpulan data wawancara, observasi dan menyalin dokumen dengan kepala madrasah, wakil kepala madrasah bidang kurikulum, bidang kesiswaan, bidang sarana prasarna, dan tata usaha, bahwa implementasi model kepemimpinan kepala madrasah MAS Mu'allimin Manba'ul Huda sesuai dengan visi madrasah yaitu unggul dalam prestasi, berakhlakul karimah, serta bermanfaat bagi masyarakat. Konsep kepemimpinan yang digunakan oleh kepala MAS Mu'allimin Manba'ul Huda adalah menerapkan kepemimpinan persfektif Islam yaitu bersifat sidik, tabligh, amanah, dan fathanah.
\end{abstract}

Kata Kunci: Model, Kepemimpinan, Kepala Madrasah.

\section{ABSTRACT}

The Visionary Leadership Model is the leader's ability to spark the idea or idea of a further vision through critical dialogue with other leaders to formulate the expected future of the organization that must be achieved through the 
commitment of all members of the organization through the process of socialization of transformation, the implementation of the ideal ideas by the leader organization. In implementing the model head MAS Mu'allimin Manba'ul Huda Bandung has its own way, such as creating a good communication pattern with all parties, establish cooperation with stakeholders, jump directly to the field to motivate subordinates and learners and find out and hone the ability owned learners. The method used in this research is descriptive-qualitativeanalytic method. Data collection techniques were conducted based on interviewing data collection techniques, observation and copying of documents with head of madrasah, deputy head of madrasah curriculum field, student field, prasarna infrastructure, and administration, that the implementation of leadership model of MAS headmaster Mu'allimin Manba'ul Huda with the vision of the madrasah is superior in achievement, berakhlakul karimah, and beneficial to society. The concept of leadership used by the head of MAS Mu'allimin Manba'ul Huda is to apply Islamic persfektif leadership that is a sidik, tabligh, amanah, and fathanah.

Keywords: Leadership Model, Head of Madrasah.

\section{PENDAHULUAN}

Kepemimpinan dapat diartikan sebagai kemampuan seseorang dalam menggerakan, mengarahkan, sekaligus mempengaruhi pola pikir, cara kerja setiap anggota agar bersikap mandiri dalam bekerja terutama dalam pengambilan keputusan untuk kepentingan percepatan pencapaian tujuan yang telah ditetapkan. (Wahyudi, 2012, h. 18)

Jika ditinjau dalam konsep Islam, tugas manusia sebagai pemimpin di bumi ini ialah memakmurkan alam sebagai manifesta dari rasa syukur manusia kepada Allah dan pengabdian kepada-Nya. Tugas Khalifah diberikan kepada setiap manusia. Dalam pelaksanaanya terkandung sikap kebersamaan atau pertanggung jawaban bersama kepada Allah SWT akan memakmurkan alam ini. Konsep ini melahirkan nilai yang sangat penting tentang "pemimpin" dan anggota atau yang dipimpin, serta situasi dimana kepemimpinan ini berlangsung. Kepemimpinan dalam Islam adalah kemampuan untuk mempengaruhi dan menggerakkan orang lain untuk mencapai tujuan yang didasari atas nilai-nilai Islam. Kepemimipnan dalam islam, sudah merupakan fitrah bagi setiap manusia. Manusia diamanahii Allah untuk menjadi khalifah di muka bumi, yang bertugas merealisasikan misi sucinya sebagai pembawa rahmat bagi alam semesta, sekaligus sebagai hamba Allah yang senantiasa patuh dan terpanggil untuk mengabdikan segenap dedikasinya di jalan-Nya.

Jabatan kepala sekolah memiliki tugas tambahan yaitu sebagai guru. Karena itu, ia harus profesional menjadi guru sekaligus kepala sekolah dengan derajat profesionalitas tertentu. Kepala sekolah memiliki fungsi yang berdimensi luas. Kepala sekolah dapat memerankan banyak fungsi, yang orangnya sama, tetapi topiknya yang berbenda. Di lingkungan Departemen Pendidikna Nasional (yang sekarang menjadi Kemendiknas) telah cukup lama dikembangkan paradigma baru administrasi atau manajemen pendidikan, dimana kepala sekolah harus minimal harus mampu berfungsi sebagai educator, manager, administator, surpervisor, leader, inavator dan motivator, disingkat EMASLIME. 
Sedangkan di Kementrian Agama (KEMENAG), dalam Peraturan Menteri Agama Republik Indonesia No. 29 Tahun 2014 Tentang Kepala Madrasah, bahwa kepala madrasah harus memiliki Kopetensi, diantaranya: kepribadian, manajerial, kewirausahaan, supervisi, dan sosial. Jika merujuk pada PERMEN DIKNAS Republik Indonesia Nomor 13 Tahun 2007 tentang Standar Kepala Sekolah/Madrasah, kepala sekolah juga harus berjiwa wirausaha atau enterpreneur. (Sudarwan Danim dan H. Khairil, 2014, h. 79)

Pada studi pendahuluan yang dilakukan peneliti berdasarkan wawancara dengan kepala madrasah, wakil kepala madrasah bidang kurikulum, serta santriwan dan santri wati pada tanggal 04 oktober 2016 di MAS Mu'allimin Manba'ul Huda Kota Bandung peneliti menemukan kepemimpinan yang berbeda dibandingkan madrasah-madrasah dan sekolah-sekolah pada umunya, selain itu juga peneliti merasakan suasana kekeluargaan yang erat sehingga antara kepala madrasah dan guru tidak canggung dalam membicarakan dan mencari solusi bersama ketika mendapat permasalahan mengenai madrasah, baik dalam administrasi, kurikulum, sarana prasarana ataupun kesiswaan. Kepemimpinan kepala madrasah di MAS Mu'allimin Manba'ul Huda ini berusaha meniru sifat-sifat terpuji (sidik, tabligh, amanah, fatanah) seperti kepemimpianan yang dilakukan oleh Rosululloh Saw saat memimpin. Kepala madrasah sangat baik hati, bijaksana, friendly, jujur dan benar-benar mendidik peserta didiknya menjadi orang yang bisa berguna bagi semua orang, serta tidak haus akan kekuasaan dan jabatan. Kepala madrasah selalu menjalankan tugasnya seperti halnya diatas, itu semua sesuai dengan visi dan misi madrasah.

\section{KAJIAN TEORI}

Pemimpin adalah seorang yang memiliki kemampuan untuk mempengaruhi dan menggerakan orang lain untuk mempengaruhi dan menggerakan orang lain untuk mencapai tujuan. Sukses tidaknya sebuah organisasi sangat tergantung dari kemampuan pemimpin dalam menggerakan seluruh anggota organisasi untuk mencapai tujuan. (Sobry Sutikno, 2014, h. 9)

Kepemimpinan dalam Islam adalah kemampuan untuk mempengaruhi dan menggerakkan orang lain untuk mencapai tujuan, yang didasari atas nilainilai Islam. (M. Sobry Sutikno, 2014, h. 85)

Pada zaman Rosululloh Saw, Rosululloh Saw secara jelas menyebutkan soal kepemimpinan dalam salah satu sabdanya, yaitu: "Setiap orang diantara kalian adalah pemimpin dan akan dimintai pertanggung jawaban atas kepemimpinanya. Seorang imam adalah pemimpin dan diminta tanggung jawab atas kepemimpinanya. Seorang suami adalah pemimpin di tengah keluarganya dan akan di minta tanggung jawab atas kepemimpinanya. Seorang istri adalah pemimpin dan akan ditanya soal kepemimpinannya. Seorang pelayanan/pegawai juga pemimpin dalam mengurus hata majikannya dan ia diminta tanggung jawabnya atas kepemimpinannya".

Kepemimpinan visioner adalah kemampuan pemimpin untuk mencetuskan ide atau gagasan suatu visi selanjutnya melalui dialog yang kritis dengan unsur pimpinan lainnya merumuskan masa depan organisasi yang dicita-citakan yang harus dicapai melalui komitmen semua anggota organisasi melalui proses sosialisasi transformasi, implementasi gagasan-gagasan ideal 
oleh pemimpin organisasin (Veithzal Rivai, dkk, 2013, h. 102). Kepemimpinan Visioner memerlukan 4 kompetensi kunci sebagimana yang dikemukakan oleh Burt Nanus, sebagai berikut:

a. Seorang pemimpin visioner harus memiliki kemapuan untuk berkomunikasi secara efektif dengan manajer dan karyawan lainnya dalam organisasi.

b. Seorang pemimpin visioner harus memahami lingkungan luar dan memiliki kemampuan bereaksi secara tepat atas segala ancaman dan peluang.

c. Seorang pemimpin harus memegang peran penting dalam membentuk dan mempengaruhi praktek organisasi, prosedur, produk dan jasa. Seorang pemimpin dalam hal ini harus terlibat dalam organisasi untuk menghasilkan dan mempertahankan kesempurnaan pelayanan, sejalan dengan mempersiapkan dan memandu jalan organisasi kemasa depan.

d. Seorang pemimpin visioner harus memiliki atau mengembangkan kemapuan untuk mengantisipasi masa depan. (M.Sobry Sutikno, 2014, h. 50)

Kepemimpinan Visioner (Visionary Leadership) adalah kemampuan pemimpin untuk menciptakan dan mengartikulasikan suatu visi yang realistik, dapat dipercaya, atraktif tentang masa depan bagi suatu organisasi atau unit organisasional yang terus bertumpu dan meningkatkan sampai saat ini (Aan Komariah dan Cepi Triatna, 2005, h. 35). Visi menyalurkan emosi dan energi orang bila diartikulasikan secara tepat, dan sebuah visi menciptakan kegairahan yang menimbulkan energi dan komitmen ditempat kerja.

\section{METODOLOGI}

Metode yang digunakan adalah metode deskriptif-kualitatifanalitik.Penelitian dilakukan di MAS Mu'allimin Manba'ul Huda yang bertempat di Jl. Cijaura Girang IV No.16 Buahbatu Kota Bandung. Sumber data melitputi : (1) Kepala Madrasah yaitu Rosihan Fahmi,M.Hum., (2)Wakil Kepala Madrasah Bidang Kurikulum yaitu Agus Rosidin, S.Pd.,(3) Wakil Kepala Madrasah Bidang Kesiswaan yaitu Uden Wilden, S.Pd.I., (4) Wakil Kepala Madrasah Bidang Sarana Prasarana yaitu Drs.Endang H., (5) Kepala Tata Usaha Hj. Fini Ruqoyah, (6) guru mata pelajaranNeni Santika, S.Pd. Teknik pengumpulan data dilakukan dengan teknik wawancara, observasi dan menyalin dokumen. Sedangkan dalam menganalisis data yang digunakan adalah analisis dengan penafsiran deskriftif semata-mata. Teknik analisis data menggunakan unitisasi, kategorisasi data, dan penafsiran data. adapun uji absah data yaitu perpanjangan keikutsertaan, ketekunan pengamatan, triangulasi, pemeriksaan teman sejawat, analisis kasus negatif, kecukupan referensi, pengecekan anggotauraian rinci, auditing untuk kriteria kebergantungan dan auditing untuk kriteria kepastian (Moleong, 2011, h. 86).

HASIL DAN PEMBAHASAN

Konsep Kepemimpinan Kepala Madrasah Aliyah Mu'allimin Manba'ul Huda 
Konsep Kepemimpinan Kepala MAS Mu'allimin Manba'ul Huda Kota Bandung telah di rancang dengan baik, diantaranya: kepala madrasah mepresentasikan dan menjelaskan konsep tersebut kepada para guru-guru, ketika semua pihak internal setuju beliau mencoba mempublikasikan kepada para stake holder, jika sesuai maka konsep tersebut di lendingkan dan melakukan percobaan terlebih dahulu terhadap peserta didik, jika hasilnya positif maka diteruskan dan jika negatif maka dihentikan dan mencari yang lebih baik lagi. Semua konsep kepala madrasah di MAS Mu'allimin Manba'ul Huda selalu di musyawarahkan terlebih dahulu kepada guru-guru MAS Mu'allimin Manba'ul Huda, sehingga semua tahu dan bebas berpendapat jika ada yang tidak sesuai, karena keputusan harus disetujui oleh internal dan bersikap demokratis tidak semauanya kepala madrasah, karena ini semua untuk kebaikan bersama dalam memajukan MAS Mu'allimin Manba'ul Huda, maka dari itu konsep kepala madrasah ini dapat dijalankan dengan baik, hal ini dapat dilihat dari hasil pelaksanaan kepemimpinan kepala madrasah Walaupun pemimpin di madrasah ini tidak terlihat religius secara penampilan, akan tetapi praktek langsung di lapangan selalu menerapkan hal-hal yang religius seperti yang telah di jelaskan di atas yaitu STAF (Sidik, Tabligh, Amanah, dan Fathanah).

MAS Mu'allimin Manba'ul Huda Kota Bandung merupakan madrasah yang memiliki pondok pesantren di bawah naungan organisasi PERSIS (Persatuan Islam), pada saat di pimpin oleh Ust. Rosihan Fahmi, M.Hum madrasah ini sangat berubah drastis, bahkan beda dengan sekolah PERSIS pada umumnya, madrasah saat ini berkembang pesat karena memiliki kualitas dan kuantitas yang baik dan bagus. Berdasarkan hasil penelitian, kepala madrasah yaitu Ust.Rosihan Fahmi, M.Hum, di balik penampilannya yang cukup unik dan tidak formal seperti layaknya kepala madrasah, bukan hanya sebatas ucapan dan pengakuan saja mengenai STAF (sidik, Tabligh, Amanah, dan Fatanah) melainkan memang benar-benar menerapkan sifat-sifat kepemimpinan persfektif Islam tersebut. Salah satu contoh yang patut kita tiru yaitu pada tahun 2008 MAS Mu'allimin Manba'ul Huda menolak adanya kunci jawaban soal UN, hingga mengadakan bakar kunci jawaban soal UN bersama.

\section{Model Kepemimpinan Kepala Madrasah}

Tanggung jawab pemimpin adalah memberikan jawaban secara arif, efektif, dan produktif atas berbagai permasalahan dan tantangan yang dihadapi, yang dilakukan bersama dengan orang-orang yang dipimpinnya, begitupun Ust. Rosihan Fahmi, M.Hum selaku Kepala MAS Mu'allimin Manba'ul Huda Kota Bandung tidak pernah meninggalkan tanggung jawabnya sebagai kepala madrasah walaupun disampin menjadi kepala madrasah beliau memiliki banyak pekerjaan lainnya. ketika ada permasalahanpun beliau selalu memecahkan bersama para bawahannya dengan demokratis agar tidak adanya kesalah pahaman anatar pemimpin dan bawahan.

Kepemimpinan Visioner memerlukan 4 kompetensi kunci sebagimana yang dikemukakan oleh Burt Nanus, sebagai berikut:

a. Seorang pemimpin visioner harus memiliki kemapuan untuk berkomunikasi secara efektif dengan manajer dan karyawan lainnya dalam organisasi. 
b. Seorang pemimpin visioner harus memahami lingkungan luar dan memiliki kemampuan bereaksi secara tepat atas segala ancaman dan peluang.

c. Seorang pemimpin harus memegang peran penting dalam membentuk dan mempengaruhi praktek organisasi, prosedur, produk dan jasa. Seorang pemimpin dalam hal ini harus terlibat dalam organisasi untuk menghasilkan dan mempertahankan kesempurnaan pelayanan, sejalan dengan mempersiapkan dan memandu jalan organisasi kemasa depan.

d. Seorang pemimpin visioner harus memiliki atau mengembangkan kemapuan untuk mengantisipasi masa depan. (M.Sobry Sutikno, 2014, h. 50)

Model Kepemimpinan Kepala Madrasah di MAS Mu'allimin Manba'ul Huda Kota Bandung adalah Model Kepemimpinan Visioner, yakni adalah kemampuan pemimpin untuk mencetuskan ide atau gagasan suatu visi selanjutnya melalui dialog yang kritis dengan unsur pimpinan lainnya merumuskan masa depan organisasi yang dicita-citakan yang harus dicapai melalui komitmen semua anggota organisasi melalui proses sosialisasi transformasi, implementasi gagasan-gagasan ideal oleh pemimpin organisasi. Adapun Kepala Madrasah dalam melakukan kegiatan berbagai bidang beliau berperan dan memiliki pengaruh baik sebagai pembimbing, pengarah, pemberi petunjuk, serta memberi bantuan kepada tenaga pendidik. Kinerja Kepala Madrasah ini sangat bagus, dibalik kesibukannya yang sangat padat selain menjadi Kepala Madrasah, beliau tidak pernah lupa dan lepas tanggung jawab sebagai Kepala Madrasah di MAS Mu'allimin Kota Bandung, bahkan berhasil menjadikan MAS mu'allimin sebagai madrasah pertama penyelenggara keterampilan di Kota Bandung mengalahkan sekolah-sekolah bagus, ternama dan elit di Bandung sesuai visi misi madrasah yang diinginkannya yaitu "Mewujudkan Madrasah yang Unggul dalam Prestasi, Mengembangkan dan Membina siswa ber-Akhlakul Karimah serta Bermanfaat bagi masyarakat". Jika dilihat dari realita yang terjadi berdasarkan penelitian, bahwa keinginan visi, misi sekolah tersebut hingga saat ini sudah tercapai, selalu dijalankan dengan baik, sehingga dari hari kehari semakin meningkat dan hampir berhasil, buktinya antara lain:

a. Unggul dalam Prestasi

MAS Mu'allimin Manba'ul Huda Kota Bandung terpilih menjadi sekolah pertama penyelenggara keterampilan di Bandung dan ke sebelas di Provinsi Jawa Barat, hal tersebut dinyatakan oleh Kantor Wilayah Kementrian Agama Provinsi Jawa Barat. Keterampilan-keterampilan yang dibuat oleh para siswasiswi disana yaitu membuat novel, karya ilmiah, yang rencananya akan diterbitkan oleh penerbit ternama yaitu Bentang Pustaka, para siswa-siswi juga harus dapat menguasai IT karena mereka biasanya dituntut untuk membuat animasi yang dipadukan dengan surat-surat pendek atau do'a-do'a harian yang dibuat menjadi CD dan di pasarkan, selain itu juga siswa-siswi mengolah daur ulang sampah seperti bungkus kopi di buat tas, taplak meja, dan yang lainnya, membuat sabun, teropong bintang, dan robot bahkan diikut sertakan lomba dan disalurkan ke UNIKOM untuk dilatih lebih dalam oleh ahlinya bahkan jika berhasil mereka mendapatkan beasiswa untuk kuliah gratis di UNIKOM. 


\section{b. Ber-Ahlakul Karimah}

Kepala MAS Mu'allimin Manba'ul Huda Kota Bandung selalu memberikan motivasi terhadap peserta didiknya sehingga kebanyakan peserta didik menyatakan bahwa kepala madrasahnya seperti motivator dan enak untuk di ajak sharing dari pada guru-gurunya. Kepala MAS Mu'allimin selalu memberikan nasehat baik kepada bawahanya maupun peserta didiknya untuk menjadi orang yang jujur, amanah, terpercaya dalam mencapai kesusksesannya dan beliau benar-benar menerapkan arti pendidikan sebenarnya yaitu ingin memanusiakan manusia karena manusia saat ini banyak yang gagal dalam pendidikan, walaupun resiko untuk menjadi orang benar, baik, jujur, amanah, terpercaya itu sangat berat seperti kasus menolak kunci jawaban UN pada tahun 2008 100\% tidak lulus, akan tetapi di balik itu semua mendapat keberkahan juga yang lebih baik yaitu semakin percayanya orang tua terhadap pihak sekolah, lebih banyaknya peminat yang ingin sekolah MAS Mu'allimin Manba'ul Huda, masyarakat menilai kualitas dan kuantitas sekolah tersebut. Selain itu juga guru-guru disana selalu memegang amanah contoh kecilnya ketika mereka memerlukan barang atau keperluan kantor dan diberikan dananya sesuai yang mereka minta tiba-tiba lebih dan masih ada kembaliannya mereka jujur dan menyatakan yang sebenarnya dan pihak sekolah pun tahu karena mereka saling terbuka sehingga dana sisasnya diberikan untuk pribadi, tanpa harus membuat bon palsu menaikkan harga barang yang di beli sehingga bersikap tidak jujur seperti realitanya orang-orang zaman sekarang kebanyakan seperti itu yang dapat di sebut juga korupsi.

c. Bermanfaat bagi Masyarakat.

Kepala MAS Mu'allimin Manba'ul Huda Kota Bandung memiliki program PKJS (Program Khidmat Jamiyyah Santri), program ini di laksanakan oleh kelas $\mathrm{XI}$, biasanya mereka di sebar ke daerah pelosok salahsatunya daerah ciwidey, mereka melakukan kegiatan membantu masyarakat disana kurang lebih selama dua minggu, hal ini dilaksanakan seperti pengabdian masyarakat atau KKN (Kuliah Kerja Nyata) yang biasanya dilakukan oleh para mahasiswa.

\section{Faktor Penunjang dan Penghambat Pelaksanaan Kepemimpinan MAS Mu'allimin Manba'ul Huda Kota Bandung}

Faktor Penunjang Pelaksanaan Kepemimpinan Kepala MAS Mu'allimin Manba'ul Huda Kota Bandung, diantaranya: Faktor Internal, yaitu yaitu terciptanya pola komunikasi yang baik antara kepala madrasah dengan para bawahannya, diterapkannya konsep Islam, yaitu kejujuran, yang menguji akhlak, nilai dan moral dalam kehidupan sehari-hari, bahwa setiap orang di MAS mu'allimin Manba'ul Huda, baik kepala madrasah, guru, tata usaha, serta peserta didik dilatih untuk bersikap jujur. Selain itu juga MAS Mu'allimin Manba'ul Huda memiliki kualitas guru yang sangat baik, diantaranya: setiap guru menguasai bahasa Inggris, bahasa Arab, dan pelajaran lain seperti matematika dll, sehingga ketika kekurangan guru, guru yang ada di sekolah dan menguasai pelajaran yang dibutuhkan dapat menggatikan walaupun bukan bidangnya. Faktor Eksternal, yaitu banyaknya stakeholder yang membantu dan mendukung program-program sekolah dalam mencapai visi, misi dan tujuan yang diinginkan sekolah, diantaranya rekan-rekan Kepala MAS Mu'allimin Manba'ul Huda Kota Bandung di luar sekolah yang peduli terhadap pendidikan, 
guru-guru, orang tua murid, masyarakat sekitar, penerbit Bentang Pustaka yang bersedia untuk bekerjasama serta stakeholder lainnya yang ikut serta membantu memajukan sekolah yang saat ini telah berhasil diraih. Selain itu terciptanya pola komunikasi yang baik antara kepala madrasah dengan guru, kepala madrasah dengan peserta murid, pihak sekolah dengan stakeholder. Faktor Penghambat Pelaksanaan Kepemimpinan Kepala MAS Mu'allimin Manba'ul Huda Kota Bandung Faktor Internal, yaitu terbatasnya Sumber Daya Manusia, terutama guru dan tata usaha, masih ada yang yang merangkap melakukan dua pekerjaan menjadi guru dan staff tata usaha, itu terjadi karena keterbatasan sarana prasarana yang belum optimal, sehingga kepala madrasah berinisiatif memberikan tugas tambahan kepada guru yang memiliki kemampuan lebih dalam administrasi untuk dijadikan staff tata usaha dalam sementara waktu. Faktor Eksternal, yaitu belum optimalnya kerjasama dengan stakeholde, masih dalam fase penjajagan (perbaikan). Contohnya dengan (1) Penerbit buku Bentang Pustaka sudah terjalin kerjasama yang baik, dengan mengadakan pelatihan menulis, namun belum sampai ke tahap peluncurran buku, karena kendalanya dari pihak peserta didik belum ada keinginan sampai ketahap tersebut, adapun salah satu peserta didik yang memiliki bakat di bidang menulis masih dalam tahap pembuatan dan belum bisa di luncurkan dan terbitkan. (2) Dengan Rock Denim juga tak jauh berbeda sama halnya dengan penerbit Bentang Pustaka tinggal menunggu minat dan kemauan dari peserta didiknya, serta waktu yang tepat.

\section{Hasil yang dicapai dalam Pelaksanaan Kepemimpinan Kepala MAS Mu'allimin Manba'ul Huda Kota Bandung}

Hasil dari pelaksanaan kepemimpinan kepala madrasah MAS Mu'allimin Manba'ul Huda Kota Bandung, yaitu tercapainya visi, misi dan tujuan madrasah sesuai yang diharapkan. Visi, misi, dan tujuan biasanya harus dicapai oleh setiap lembaga pendidikan, akan tetapi kebanyakan sekolah berjalan tidak sesuai visi, misi, dan tujuan yang telah di rencanakan dan di rancang. Madrasah MAS Mu'allimin Manba'ul Huda berhasil menjalankan kepemimpinannya menggunakan model kepemimpinan visioner.

Visi MAS Mu'allimin Manba'ul Huda yaitu Mewujudkan Madrasah yang Unggul dalam Prestasi, Mengembangkan dan membina siswa ber-Akhlakul Karimah serta Bermanfaat bagi Masyarakat. Dari visi tersebut $80 \%$ terlaksana, buktinya saat ini dalam hal prestasi MAS Mu'allimin telah ditunjuk oleh Kantor Wilayah Kementrian Agama Islam Provinsi Jawa Barat sebagai sekolah penyelenggara keterampilan nomor satu di Bandung, dan ke sebelas di tingkat Provinsi Jawa Barat. Sedangkan dalam hal ber-Akhlakul Karimah, MAS Mu'allimin Manba'ul Huda mencoba meningkatkan iman dan takwa berdasarkan Al-Qur'an dan Sunnah, kepada seluruh keluarga MAS Mu'allimin Manba'ul Huda melalui pelajaran kepesantreanan dan mata pelajaran lainnya, salah satunya menerapkan prilaku jujur, baik dalam belajar mauapun dalam kegiatan sehari-hari, kepada teman,guru terutama kepeada Allah SWT dan Bermanfaat bagi Masyarakat, peserta didik MAS Mu'allimin Manba'ul Huda sudah dibiasakan untuk terjun ke dalam lingkungan masyarakat, kepala Madrasah telah membuat program kegiatan praktek pengabdian masyarakat sepeti halnya yang selalu dilakukan oleh mahasiswa semester akhir yaitu 
Kuliah Kerja Nyata, yang wajib dilaksanakan oleh peserta didik kelas XI, kegiatan ini bertujuan untuk melatih peserta didik bersosialisasi yang baik serta dapat bermanfaat bagi masyarakat sekitar setelah menyelesaikan sekolah di tigkat Madrasah Aliyah dan melanjutkan kuliah atau terjun langsung kedalam dunia pekerjaan yang sangat banyak tantangannya dan harus pandai bersosialisasi dengan orang-orang sekitar.

\section{SIMPULAN}

Kepemimpinan yang digunakan oleh MAS Mu'allimin Manba'ul Huda yaitu Kepemimpinan persfektif Islam, semua guru dan peserta didik menerapkan sifat sidik,tabligh, amanah, dan fathonah. Selain itu juga tipe kepemimpinan MAS Mu'allimin adalah demokratis, kepala MAS Mu'allimin Manba'ul Huda sangatalah terbuka kepada bawahannya serta selalu mendelegasikan bawahannya. Model Kepemimpinan MAS Mu'allimin Manba'ul Huda yaitu Model Kepemimpinan Visioner, kepala MAS Mu'allimin Manba'ul Huda telah berhasil menjalankan visi madrasah sebagai sekolah unggul berprestasi, berakhlakul kharimah, serta berguna bagi masyarakat. Hasil dari visi tersebut, bahwa MAS Mu'allimin telah berhasil meraih penghargaan dari Kanwil Kementrian Agama Provinsi Jawa Barat sebagai sekolah penyelenggara ketermpilan nomor satu di Bandung, dan kesebelas di tingkat Jawa Barat. Faktor penunjang yakni terciptanya pola komunikasi yang baik antara bawahan dan atasan, terjalinnya kerjasama dengan stakeholder yang peduli terhadap keberlangsungan proses belajar mengajar di MAS Mu'allimin Manba'ul Huda. Sedangkan Faktor Penghambatn yakni terbatasnya Sumber Daya Manusia, seperti guru dan staf tata usaha, serta belum optimalnya kerjasama dengan stakeholder dan masih dalam tahap penjajagan.

\section{DAFTAR PUSTAKA}

Komariah, A. \& Triatna, C. (2005). VISIONARY KEPEMIMPINAN Menuju Sekolah Efektif. Jakarta: Bumi Aksara

Moleong, L. J. (2011). Metodologi Penelitian Kualitatif. Bandung: Remaja Rosda Karya

Sutikno, M. S. (2014). Pemimpin dan Kepemimpinan. Lombok: Holistica Peraturan Mentri Agama RI. (2014). "Kepala Madrasah BAB IV Pasal 8"

Sudarwan, D \& Suparno. (2009). Manajemen dan Kepemimpinan Transformasional Kepala Seklah. Jakarta: Rineka Cipta

Sudarwan, D. \& Khairil, H. (2013). Profesi Kependidika. Bandung: ALFABETA Wahyudi. (2012). Kepemimpinan Kepala Sekolah . Bandung: ALFABETA 
Astuti 